\title{
Secretion by Glucagonomas of a Possible
}

\section{Glucagon Precursor}

\author{
Gordon C. Weir, Edward S. Horton, Thomas T. Aoki, David Slovik, \\ JONATHAN JASPAN, and ARTHUR H. RUBENSTEIN
}

From the Department of Medicine, Massachusetts General Hospital, Boston, Massachusetts 02114, E. P. Joslin Research Laboratory, Harvard Medical School, Boston, Massachusetts 02115, the

Department of Medicine, the University of Vermont College of Medicine, Burlington, Vermont 05401, and the Department of Medicine, University of Chicago, Chicago, Illinois 60637

A B S T RACT Five patients with glucagonomas had elevated plasma levels of total glucagon immunoreactivity. Gel filtrations of these plasma samples on Bio-Gel P30 columns showed that most of the immunoreactivity eluted in the 3,500-(true glucagon) and 9,000-dalton fractions. After the administration of alpha cell effectors, changes in total glucagon immunoreactivity were seen which were accounted for primarily by the 3,500 -dalton species, but there were also changes in the 9,000-dalton moiety. Venous effluent plasma from tumors of two subjects contained elevated concentrations of glucagon immunoreactivity in both fractions. When material from both the 3,500and 9,000-dalton peaks were serially diluted in a glucagon immunoassay, parallel displacement curves were found, suggesting that both have similar or identical antigenic determinants. Thus, with conversion to a neoplastic state, alpha cells of glucagonomas, much like beta cells of insulinomas, may secrete an increased amount of a larger, 9,000mol wt glucagon species which may be a prohormone.

\section{INTRODUCTION}

It has only recently been appreciated that patients with glucagon-producing pancreatic tumors may have a constellation of conditions which include a dermatitis termed necrolytic migratory erythema, weight loss, anemia, stomatitis, impaired glucose tolerance, hypoaminoacidemia, and elevated plasma glucagon levels $(1,2)$. Patients with these conditions have been considered as having the glucagonoma syndrome (1). With

Parts of this work were presented at the Annual Meeting of the American Diabetes Association, June 1976, San Francisco, Calif.

Received for publication 6 September 1976 and in revised form 18 October 1976. the availability of the glucagon radioimmunoassay and a growing awareness of this syndrome, increasing numbers of patients with this disorder are being found. Five patients with glucagon-producing tumors have recently been evaluated by us, providing an opportunity to characterize the different forms of plasma glucagon immunoreactivity and to determine whether neoplastic alpha cells, like insulinomas (3), secrete increased amounts of an immunoreactive moiety, larger than the normal predominant secretory product.

\section{METHODS}

\section{Patients}

Patient J. D. A 40-yr-old male was admitted to the Massachusetts General Hospital in November 1974, with a 2-yr history of weight loss and a 7-mo history of a skin rash, which was later considered typical of necrolytic migratory erythema. In addition, he had an abnormal glucose tolerance test (fasting plasma glucose, $95 \mathrm{mg} / \mathrm{dl} ; 1 \mathrm{~h}, 211$; and $2 \mathrm{~h}, 174$ ), stomatitis, anemia, and hepatomegaly. Hypoaminoacidemia was present, and a fasting immunoreactive glucagon level was $2,200 \mathrm{pg} / \mathrm{ml}$. A needle biopsy of the liver showed small, regular tumor cells, and glucagon was demonstrated in these cells using the horseradish peroxidase technique with a rabbit antiglucagon antibody. A selective celiac angiogram revealed a focal area of hypervascularity in the body of the pancreas and multiple discrete hepatic masses. This patient has been described in greater detail as a clinicopathological exercise (4).

Patient H. E. A 39 -yr-old male was admitted to the Massachusetts General Hospital with a 4-yr history of skin rash and weight loss. He had been treated with large doses of systemic and topical corticosteroids for the rash. Upon admission, his rash was diagnosed as necrolytic migratory erythema. He had hypoaminoacidemia, a fasting plasma glucagon of 800 $\mathrm{pg} / \mathrm{ml}$, and an abnormal glucose tolerance curve (fasting plasma glucose, $93 \mathrm{mg} / \mathrm{dl}$; $1 \mathrm{~h}, 253$; and $2 \mathrm{~h}, 226$ ). A selective celiac angiogram revealed a vascular $4 \times 6-\mathrm{cm}$ mass in the tail of the pancreas. The mass was removed by surgery and histology showed small cells with invasive characteristics. The concentration of glucagon immunoreactivity found in 
the tumor was $120 \mu \mathrm{g} / \mathrm{g}$ tissue. Although no metastases were discovered during his initial surgery, multiple hepatic metastases were found a year later, which pathologically resembled the primary tumor.

Patient F. L. A 53-yr-old female was admitted to the Mary Fletcher Hospital, Burlington, Vt, in June 1975, with a 1-yr history of weight loss, an 8-mo history of skin rash, and an abnormal glucose tolerance test (fasting blood sugar, $96 \mathrm{mg} / \mathrm{dl}$; lh, 242; and $2 \mathrm{~h}, 181$ ), 2 mo before admission. The rash was typical of necrolytic migratory erythema and a fasting plasma glucagon was $790 \mathrm{pg} / \mathrm{ml}$. Abdominal exploration revealed an elipsoid mass in the tail of the pancreas measuring approximately $10 \mathrm{~cm}$ in its long diameter. There was no evidence of metastases. Histologically, the tumor consisted of alpha cells without evidence of malignant change and the concentration of glucagon immunoreactivity in the tumor was $100 \mu \mathrm{g} / \mathrm{g}$ tissue.

Patient M. C. This 58-yr-old female was admitted to the Mary Hitchock Memorial Hospital, Hanover, N. H., in March 1974, with a 1-mo history of skin rash, stomatitis, and a 10-pound weight loss. Multiple tumor nodules were seen on a liver scan. Tissue from a liver biopsy was initially thought to represent hepatoma, but later electron microscope examination revealed alpha cell-like granules. Celiac angiography showed highly vascular hepatic tumors with a probable blush in the tail of the pancreas. In January 1976, her skin rash was interpreted as necrolytic migratory erythema and her oral glucose tolerance test was diabetic, with a fasting blood glucose level of $180 \mathrm{mg} / \mathrm{dl}$; $1 \mathrm{~h}, 412$; and $2 \mathrm{~h}, 342$. A fasting glucagon level was $2,700 \mathrm{pg} / \mathrm{ml}$.

Patient W. A. This 62-yr-old female was a patient at the University of Chicago Hospital. She had a 5-yr history of diabetes which had been poorly controlled on insulin with recurrent episodes of nonketotic hyperglycemia requiring hospitalization. On her final hospital admission, she was comatose with marked nonketotic hyperglycemia (blood glucose level $600 \mathrm{mg} / \mathrm{dl})$, focal neurological signs, and pneumonia. She initially responded to an infusion of insulin, but then developed focal motor seizures and expired. Necropsy, $6 \mathrm{~h}$ after death, revealed cerebral thrombosis, bronchopneumonia, myocardial infarction, and a $0.4-\mathrm{cm}$ nodule protruding from the body of the pancreas. This was a well-differentiated islet cell carcinoma with distinct invasion at the periphery of the lesion. The Grimelius silver strain was positive, the tumor cells showing characteristic alpha cell granules. Electron microscopy likewise showed alpha cell-like granules. Large amounts of glucagon immunoreactivity were found in the tumor by immunofluorescence. Serum withdrawn at necropsy from the subclavian vein had an immunoreactive glucagon value of $1,400 \mathrm{pg} / \mathrm{ml}$. To rule out the possibility that this elevation was a postmortem artifact, serum was obtained from seven postmortem control cases. The necropsy interval varied between 6 and $24 \mathrm{~h}$ and glucagon levels ranged between 23 and $191 \mathrm{pg} / \mathrm{ml}$.

\section{Collection of samples}

$100 \mathrm{~g}$ of glucose as Dexicola was given to patients F. L. and $\mathrm{H}$. E., and the samples used for the analysis in Table II were drawn $30 \mathrm{~min}$ later. For patient F. L., an intravenous infusion of glucose $(100 \mathrm{mg} / \mathrm{min})$ was begun $45 \mathrm{~min}$ after the oral glucose and this was continued until $260 \mathrm{~min}$. In addition, $25 \mathrm{~g}$ glucose was given intravenously between 55 and $60 \mathrm{~min}$. A sample for fractionation was drawn at $240 \mathrm{~min}$. Arginine was infused intravenously into patients F. L. and M. C. at the rate of $12 \mathrm{mg} / \mathrm{kg}$ per min with samples drawn 30 min after the initiation of the infusion. During surgery, a sample was obtained from the splenic vein of patient $H$. E., and $1 \mathrm{~min}$ before this, a peripheral venous specimen was drawn. Similarly, at surgery, a sample was drawn from a vein draining the tumor of patient F. L. and a sample from the splenic artery was obtained as well. The blood samples were collected in tubes containing $500 \mathrm{U}$ Trasylol (Delbay Pharmaceuticals, Bloomfield, N. J.) and either $1 \mathrm{mg}$ of EDTA
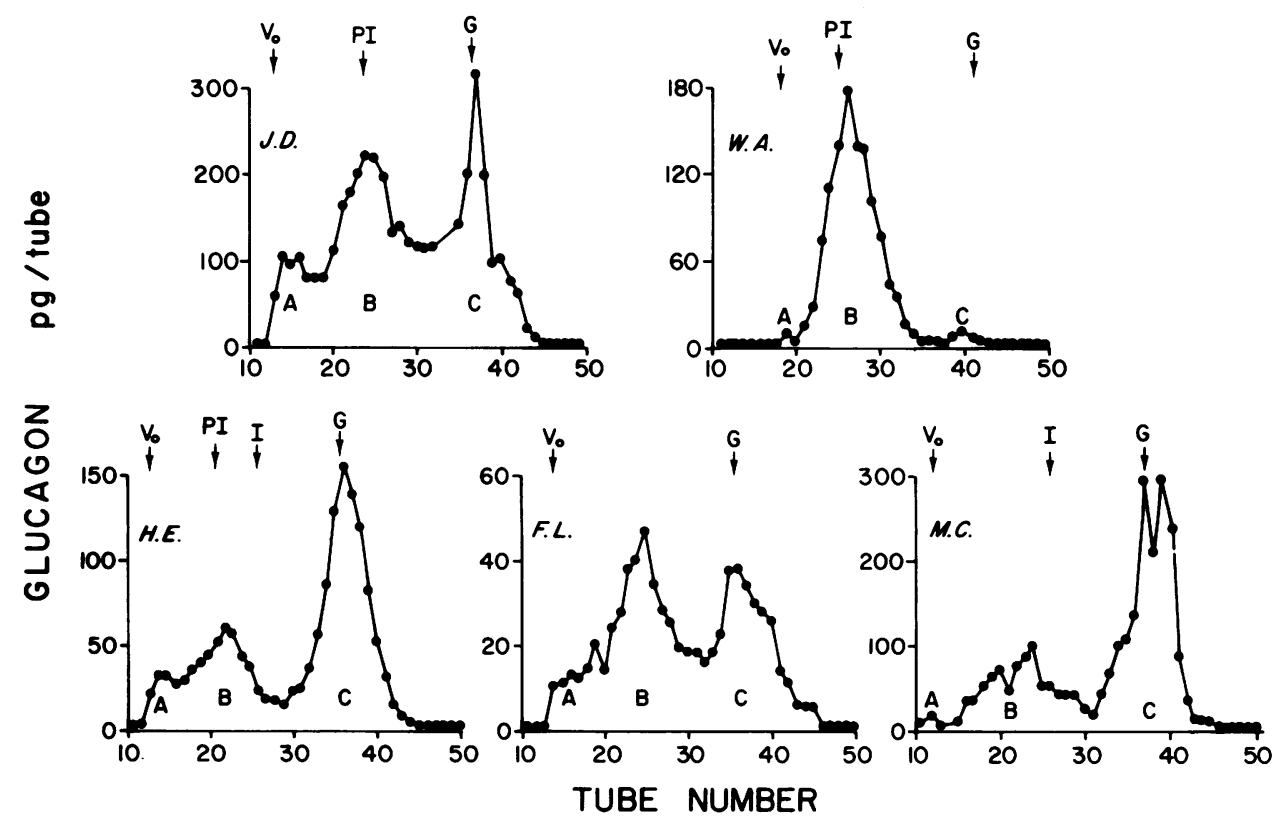

FIGURE 1 Gel filtration elution profiles of plasma from five patients with glucagonomas. Markers used to calibrate the Bio-Gel P30 columns include ${ }^{131} \mathrm{I}$-proinsulin (PI), ${ }^{125} \mathrm{I}$-insulin (I), and ${ }^{125} \mathrm{I}$ glucagon $(G) . V_{0}$ refers to the void volume. 
or $12 \mathrm{U}$ of heparin/ml of blood. Written informed consent for the studies was obtained from each patient.

\section{Assay techniques}

Immunoreactive glucagon levels on the plasma of subjects H. E., J. D., F. L., and M. C. were measured by radioimmunoassay using dextran-charcoal separation and antiserum $30 \mathrm{~K}$ obtained from Dr. R. Unger (5). The plasma determination of patient W. A. was determined by a double-antibody radioimmunoassay also using antiserum $30 \mathrm{~K}(6)$.

\section{Gel filtration}

Plasma samples from patients H. E., J. D., F. L., and M. C., with a volume ranging from 0.2 to $0.8 \mathrm{ml}$, were filtered on a $46 \times 1-\mathrm{cm}$ Bio-Gel-P30 column (Bio-Rad Laboratories, Richmond, Calif.) at $4^{\circ} \mathrm{C}$. The elution buffer was $0.2 \mathrm{M}$ glycine, $\mathrm{pH} 8.8$, with $0.25 \%$ bovine serum albumin, $1 \%$ lamb serum, and $0.5 \%$ merthiolate. $0.7-\mathrm{ml}$ fractions were collected and the glucagon immunoreactivity determined by radioimmunoassay (5). The sample from patient $W$. A. was filtered on a $50 \times 1-\mathrm{cm}$ Bio Gel-P30 column at room temperature, the eluent being $0.2 \mathrm{M}$ glycine buffer, $\mathrm{pH} \mathrm{8.8,} \mathrm{contain-}$ ing $0.25 \%$ human albumin, $1 \%$ lamb serum, and $500 \mathrm{U} / \mathrm{ml}$ Trasylol. 1-ml fractions were collected and the total volume measured by radioimmunoassay (6). Recovery of the eluted immunoreactivity was approximately $80 \%$. It was assumed that the distribution of immunoreactivity in peaks A, B, and $\mathrm{C}$ in the collected fractions was identical to their distribution in plasma samples. Accordingly, the amount of immunoreactivity in various fractions (Tables I-III) was calculated by multiplying the relative amounts of material in each peak (expressed as percent of total immunoreactivity of all the fractions) by the concentration of total plasma glucagon immunoreactivity as determined by radioimmunoassay. Columns were calibrated with blue dextran, ${ }^{131}$ I-proinsulin, ${ }^{125} \mathrm{I}$-insulin, and ${ }^{125} \mathrm{I}$-glucagon.

\section{RESULTS}

Fasting plasma samples from five patients with glucagonomas were chromatographed on Bio-Gel P30 and the elution profiles are depicted in Fig. 1, with the distribution of immunoreactivity in peaks $\mathrm{A}, \mathrm{B}$, and $\mathrm{C}$ noted in Table $\mathrm{I}$. The most noteworthy finding is that there is a large amount of immunoreactive material in peak $\mathrm{B}$, the 9,000 -mol wt region. This contrasts markedly with the either absent or minimal amounts of this component found in normal subjects $(7,8)$. The relative amount of peak $B$ material in patient W. A. is extremely high $(97.5 \%)$, but this plasma was obtained $6 \mathrm{~h}$ postmortem, and it is possible that some peak $\mathrm{C}$ material was degraded. The amount of peak A or void volume immunoreactivity in these subjects must be interpreted with caution because there was usually poor discrimination between the small peak $A$ and the larger peak $B$.

The tumors were responsive to stimulation or suppression as indicated (Table II) by the increases in total glucagon immunoreactivity during the infusion of arginine and $30 \mathrm{~min}$ after oral glucose, and the de-
TABLE I

Fractionation of Fasting Plasma

\begin{tabular}{|c|c|c|c|c|}
\hline Patient & $\begin{array}{c}\text { Total } \\
\text { glucagon } \\
\text { immuno- } \\
\text { reactivity }\end{array}$ & $\begin{array}{l}\text { Peak A } \\
\text { (void) }\end{array}$ & $\begin{array}{c}\text { Peak B } \\
(9,000 \text { mol wt })\end{array}$ & $\begin{array}{c}\text { Peak C } \\
(3,500 \mathrm{~mol} \text { wt })\end{array}$ \\
\hline & $p g / m l^{*}$ & $\% \ddagger$ & $\%$ & $\%$ \\
\hline J. D. & 2,200 & $14.5(319) \S$ & $46.9(1,032)$ & (849) \\
\hline H. E. & 760 & 7.0 & $31.6 \quad(240)$ & (467) \\
\hline F. L. & 900 & $11.4(103)$ & (442) & $39.5 \quad(355)$ \\
\hline M. C. & 2,700 & $2.3 \quad(62)$ & $24.0 \quad(648)$ & $73.7(1,990)$ \\
\hline W. A." & 1,400 & (14) & $97.5(1,365)$ & $1.5 \quad(21)$ \\
\hline
\end{tabular}

* Concentrations obtained by immunoassay of plasma samples.

$\ddagger$ Percentage values refer to the amount of glucagon immunoreactivity in each peak as a percentage of the total immunoreactivity of all fractions.

$\$$ Concentration in picograms per milliliter of each peak calculated from the total plasma glucagon immunoreactivity. "Sample obtained $6 \mathrm{~h}$ postmortem.

crease after intravenous glucose. When the various fractions were analyzed, it is apparent that most of the change in total immunoreactivity can be accounted for by peak $\mathrm{C}, 3,500$-mol wt glucagon. There are also definite changes in the 9,000 -mol wt peak B. Peak A (void volume) values are difficult to interpret for the reasons indicated above and the changes were relatively small.

TABLE II

Fractionation of Plasma after Administration of Alpha Cell Effectors*

\begin{tabular}{|c|c|c|c|c|c|}
\hline Patient & Test & $\begin{array}{l}\text { Total } \\
\text { glucagon } \\
\text { immuno- } \\
\text { reactivity }\end{array}$ & $\begin{array}{c}\text { Peak A } \\
\text { (void) }\end{array}$ & $\begin{array}{c}\text { Peak B } \\
(9,000 \\
\text { mol wt })\end{array}$ & $\begin{array}{c}\text { Peak C } \\
(3,500 \\
\text { mol wt })\end{array}$ \\
\hline & & $p g / m l$ & $\%$ & $\%$ & $\%$ \\
\hline \multirow[t]{5}{*}{ F. L. } & Fasting & 900 & $11.4(103)$ & $49.1(442)$ & $39.5 \quad(355)$ \\
\hline & $\begin{array}{c}\text { P.O. Glucose } \\
-30 \mathrm{~min}\end{array}$ & 1,580 & 8.7 (137) & 46.7 (738) & $44.6 \quad(705)$ \\
\hline & $\begin{array}{l}\text { I.V. Glucose } \\
-240 \mathrm{~min}\end{array}$ & 535 & $14.6 \quad(78)$ & $51.0(273)$ & $34.4 \quad(184)$ \\
\hline & Fasting & 840 & $9.7 \quad(81)$ & 47.5 (399) & $42.8 \quad(360)$ \\
\hline & $\begin{array}{l}\text { Arginine } \\
\qquad-30 \mathrm{~min}\end{array}$ & 1,500 & $4.3 \quad(65)$ & $38.1(572)$ & $57.6 \quad(863)$ \\
\hline \multirow[t]{2}{*}{ H. E. } & Fasting & 760 & $7.0 \quad(53)$ & $31.6(240)$ & 61.4 \\
\hline & $\begin{array}{c}\text { P.O. Glucose } \\
-30 \mathrm{~min}\end{array}$ & 1,520 & $3.7 \quad(56)$ & $23.2(353)$ & $73.1(1,111)$ \\
\hline \multirow[t]{2}{*}{ M. C. } & Fasting & 2,700 & $2.3 \quad(62)$ & $24.0(648)$ & $73.7(1,990)$ \\
\hline & $\begin{array}{l}\text { Arginine } \\
\quad-30 \mathrm{~min}\end{array}$ & 5,200 & $2.1(109)$ & $18.7(972)$ & $79.2(4,118)$ \\
\hline
\end{tabular}

* Concentrations and percentages determined as in Table I. 
TABLE III

Fractionation of Plasma from Venous Effluent of Glucagonomas*

\begin{tabular}{|c|c|c|c|c|c|}
\hline Patient & Source & $\begin{array}{l}\text { Total } \\
\text { glucagon } \\
\text { immuno- } \\
\text { reactivity }\end{array}$ & $\begin{array}{c}\text { Peak A } \\
\text { (void) }\end{array}$ & $\begin{array}{c}\text { Peak B } \\
(9,000 \\
\text { mol wt })\end{array}$ & $\begin{array}{c}\text { Peak C } \\
(3,500 \\
\text { mol wt })\end{array}$ \\
\hline & & $\mathrm{pg} / \mathrm{ml}$ & $\%$ & $\%$ & $\%$ \\
\hline \multirow[t]{2}{*}{ H. E. } & $\begin{array}{l}\text { Peripheral } \\
\text { vein }\end{array}$ & 790 & $8.5 \quad(67)$ & $22.7 \quad$ (179) & $68.8 \quad(544)$ \\
\hline & $\begin{array}{l}\text { Venous } \\
\text { effluent }\end{array}$ & 10,000 & $3.7(370)$ & $19.0(1,900)$ & $77.3(7,730)$ \\
\hline \multirow[t]{2}{*}{ F. L. } & Arterial & 2,295 & 7.6 (174) & $31.8 \quad(730)$ & $60.6(1,391)$ \\
\hline & $\begin{array}{l}\text { Venous } \\
\text { effluent }\end{array}$ & 12,000 & $3.1 \quad(372)$ & $19.4(2,328)$ & $77.5(9,300)$ \\
\hline
\end{tabular}

* Concentrations and percentages determined as in Table I.

Before surgical removal, samples were obtained from veins draining the tumors of two patients. When compared with a peripheral venous sample in one patient and an arterial sample in the other, a marked increment of total glucagon immunoreactivity was seen in the venous effluent (Table III). As with the secretory changes described above, most of the increase was accounted for by peak $\mathrm{C}$ material. In addition, however, there was a clear increment in the 9,000-mol wt, peak B, which was particularly obvious in patient H. E. Peak A immunoreactivity also appeared to be increased. Thus, tumor drainage studies indicate that these two glucagonomas secrete primarily 3,500 mol wt glucagon and relatively smaller amounts of the 9,000-mol wt moiety.

Tumor tissue from patients $\mathrm{H}$. E. and F. L. was extracted in $2 \mathrm{~N}$ acetic acid, diluted in glycine buffer and chromatographed in Biogel-P30. The elution profile of the tumor tissue of patient H. E. is depicted in the lower panel of Fig. 2, where a dominant peak in the 3,500 -mol wt region is seen. Additional immunoreactive material extends from the void volume to the glucagon peak, but it is difficult to appreciate any clearly defined peaks which correspond to the specific plasma components. In the upper panel are two elution profiles of different amounts of tumor extract from patient F. L. As indicated by the solid line, a large peak is seen in the glucagon region, but only small amounts of higher molecular weight material are present. When larger amounts of extract were chromatographed (depicted by the dashed line), higher molecular weight immunoreactivity can be seen, but definite peaks were not detected.

Further studies were performed to compare the immunoreactive characteristics of peaks $B$ and $C$ with glucagon standard. Plasma from two patients was chromatographed and fractions of peak $B$ and $C$ were separately pooled (patient H. E., 24-31, and 42-46; patient J. D., 23-28, and 41-42). When different volumes from each pool were assayed, parallel displacement curves were found, indicating similar immunologic reactivity of these components with antiserum 30K (Fig. 3).

\section{DISCUSSION}

In recent years the heterogeneity of glucagon immunoreactivity in human plasma has become increasingly complex, and at least five forms have thus far been described. Total plasma glucagon immunoreactivity in fasting normal man is found to be approximately $100 \mathrm{pg} / \mathrm{ml}$ in most laboratories. The majority of this glucagon immunoreactivity, although there is considerable individual variation, is accounted for by a moiety with an estimated mol wt of 160,000 which has been termed the interference factor $(5,9)$, big plasma glucagon (7), or perhaps more accurately, big plasma glucagon immunoreactivity. This fraction makes up about $55 \%$ of the total glucagon immunoreactivity (7-9). Most of the remaining glucagon immunoreactivity, approximately $35 \%$, is accounted for by a 3,500-mol wt glucagon (7-9). An additional

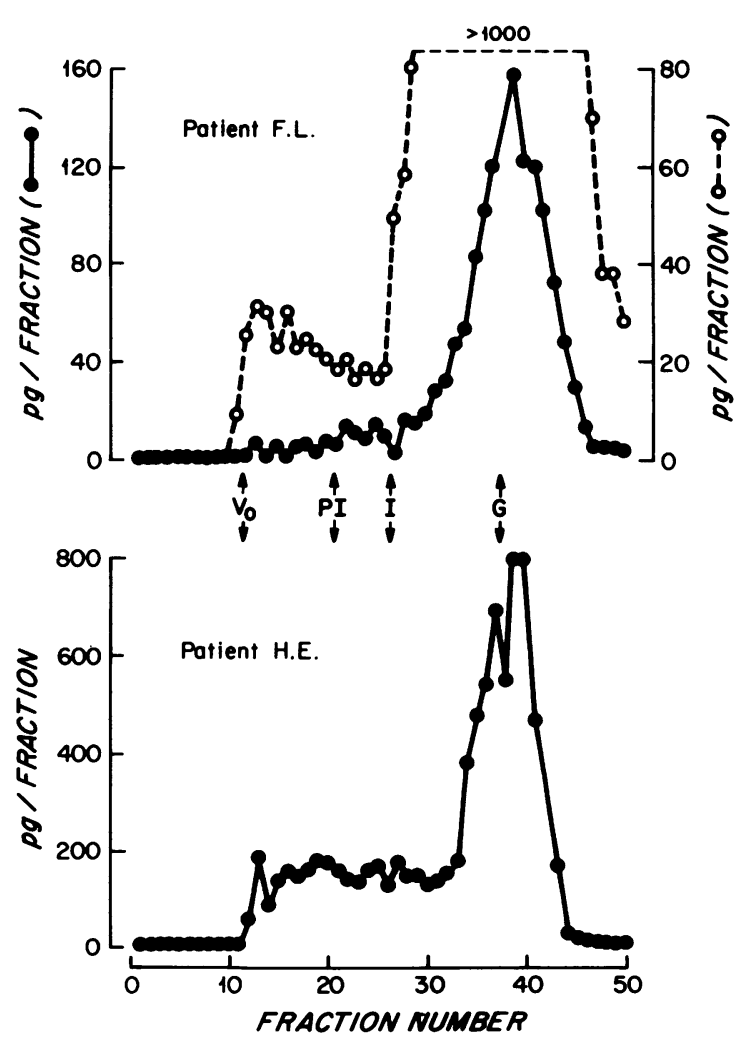

Figure 2 Gel filtration of elution profiles of extracts from tumors of two patients. The two profiles in the upper panel represents different amounts of extract from patient $F$. $L$. The $46 \times 1-\mathrm{cm}$ Bio-Gel P30 column was calibrated as in Fig. 1 . 
component, which has a mol wt of $9,000(7,8)$, may be a precursor form of glucagon and is perhaps identical to material with a similar molecular size called large glucagon immunoreactivity which has been identified in pancreatic tissue extracts (10). This is not usually found in the plasma of normal subjects but is consistently seen in patients with renal failure (8). A $10,000-20,000$-mol wt form has recently been described in a family with increased levels of total glucagon immunoreactivity (11) and Valverde et al. (7) have found a smaller 2,000-mol wt form which is present in very small amounts.

Patients with glucagonomas have an increased level of total glucagon immunoreactivity as would be expected from their large alpha cell mass, and after fractionation much of this material elutes as 3,500 mol wt, "true" glucagon. In addition, the concentration of the 9,000-dalton form is markedly increased, both in terms of absolute amount and also in a relative sense when compared with the quantity of true glucagon. After the administration of various alpha cell effectors, such as glucose given orally or intravenously, or intravenous arginine, there are significant changes in total glucagon immunoreactivity which presumably reflect changes in alpha cell secretion. The increase of glucagon after oral glucose in two of our patients contrasts with the depression found in normal subjects (12), but has previously been reported (13). Most of the increase after glucose or arginine administration can be accounted for by the $3,500-\mathrm{mol}$ wt glucagon, but there is also a contribution from the $9,000-\mathrm{mol}$ wt form. Further evidence that this larger form is a secretory product of the neoplastic alpha cells is provided by the finding of increased levels of the 9,000dalton species in the venous effluent from two tumors. It is not clear whether impaired clearance mechanisms may also have contributed to the increased glucagon levels because specific clearance studies were not performed. However, renal function as assessed by blood urea nitrogen and creatinine was normal in four of the patients.

The size of peak A material, which is greater than 9,000 daltons, has not been determined accurately in this study, but it may represent big plasma glucagon immunoreactivity which has previously been found to have an approximate mol wt of 160,000 daltons $(7,8)$. The suggestion that this void volume material is secreted (Table III) must be interpreted with caution. The relatively small peak $A$ is difficult to discriminate from the larger peak $B$, and at present there is no definitive evidence that big plasma glucagon immunoreactivity is secreted by either normal or abnormal alpha cells.

The identity of the $9,000-\mathrm{mol}$ wt material with glucagon immunoreactivity has not yet been clarified. Even though the existence of a glucagon biosynthetic pre-

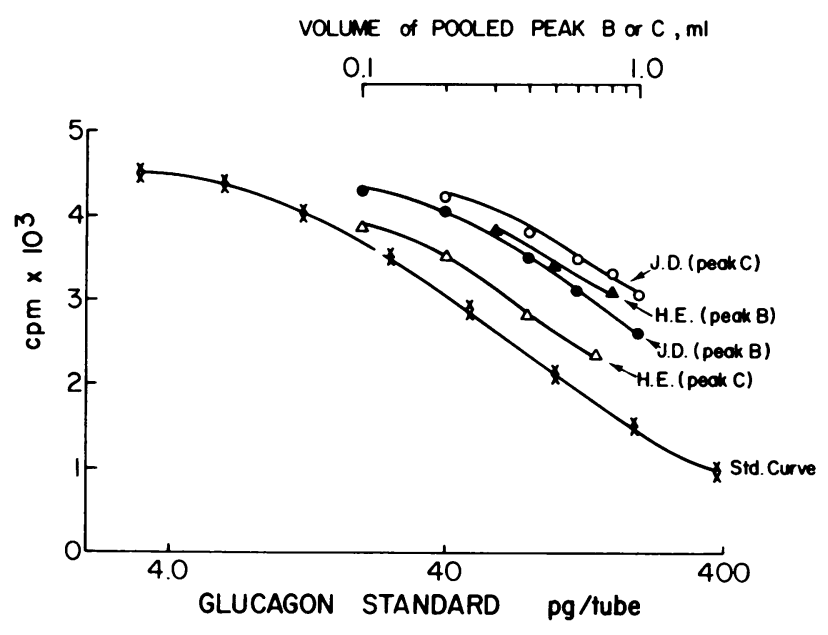

FIGURE 3 Comparison of displacement curves produced by measuring increasing amounts of material from the pooled fractions of peaks B and C (from patients J. D. and H. E.) in the glucagon radioimmunoassay. Porcine glucagon was used for the standard curve.

cursor has not been conclusively proven, there is persuasive evidence that a larger molecule (or molecules) is sequentially cleaved to glucagon (14). Studies in islet tissue from a number of species including humans (14-17) indicate that $\left[{ }^{3} \mathrm{H}\right]$ tryptophane is incorporated into a peptide of about 9,000 daltons. In addition, material of this weight with glucagon immunoreactivity has been found in pancreatic extracts from several species (10). It thus seems likely that one of what might be several glucagon precursor forms has a mol wt of about 9,000 . With the present data indicating that the 9,000-dalton species of glucagonoma patients is an alpha cell secretory product, it is reasonable to postulate that this material represents a biosynthetic precursor of glucagon. It may be significant that the immunologic displacement curve of peak B material is parallel to the curves of glucagon standard and peak $C$. This suggests that the $9,000-\mathrm{mol}$ wt species and true glucagon have common antigenic determinants. Despite this immunologic similarity, the 9,000-dalton material found in pancreatic tissue, which may be identical to the plasma component of the same size, is devoid of glycogenolygic activity (10).

Valverde et al. (18) have chromatographed plasma from a patient with a suspected glucagonoma and have found an elution profile of glucagon immunoreactivity very similar to those reported in the present study. In addition, Danforth et al. (19) have found evidence for an immunoreactive species of about 9,000 daltons in a patient with an alpha cell tumor. Although large forms of several hormones have been found in plasma (20-26), only proinsulin has been convincingly shown to be preferentially secreted by neoplastic tissue (3). Therefore neoplasia of both alpha and beta cells 
apparently leads to abnormal secretion of larger, presumably precursor, peptides. The mechanisms responsible for these changes have not yet been fully elucidated nor has the potential clinical usefulness of assisting with diagnosis or following the progress of treatment been explored in detail.

\section{ACKNOWLEDGMENTS}

The authors wish to thank Robert F. Atkins and Pareskevy C. Goltsos for their technical assistance, and Mrs. Helen Holbrook for preparation of the manuscript.

This work was supported by research grants from the National Institutes of Health (AM 18230, General Clinical Research Center, Burlington, Vt., RR-109, AM 13941, The Diabetes-Endocrinology Center at the University of Chicago, AM 17046), and the A. L. Parker Foundation.

\section{REFERENCES}

1. Mallinson, C. N., S. R. Bloom, A. P. Warin, P. R. Solomon, and B. Cox. 1974. A glucagonoma syndrome. Lancet. II: 1-5.

2. McGavran, M. H., R. H. Unger, L. Recant, H. C. Polk, C. Kilo, and M. E. Levin. 1966. A glucagon-secreting alphacell carcinoma of the pancreas. N. Engl.J.Med. 274: 14081413.

3. Rubenstein, A. H., M. E. Mako, J. I. Starr, D. J. Juhn, and D. L. Horwitz. 1974. Circulating proinsulin in patients with islet cell tumors. Proceedings of the 8th Congress of the International Diabetes Foundation, Brussels, 15-20 July 1973. W. J. Malaisse and J. Pirat, editors. Excerpta Medica, Amsterdam. 736-752.

4. Scully, R. E., editor. 1975. Weekly clinicopathological exercises. Case 20-1975. Case Records of the Massachusetts General Hospital. N. Engl. J. Med. 292: 1117-1123.

5. Weir, G. C., R. C. Turner, and D. B. Martin. 1973. Glucagon radioimmunoassay using antiserum $30 \mathrm{~K}$ : Interference by plasma. Horm. Metab. Res. 5: 241-244.

6. Kuku, S. F., A. Zeidler, D. S. Emmanouel, A. I. Katz, A. H. Rubenstein, N. W. Levin, and A. Tello. 1976. Heterogeneity of plasma glucagon: Patterns in patients with chronic renal failure and diabetes. J. Clin. Endocrinol. Metab. 42: 173-176.

7. Valverde, I., M. L. Villaneuva, I. Lozano, and J. Marco. 1974. Presence of glucagon immunoreactivity in the globin fraction of human plasma ("big plasma glucagon"). J. Clin. Endocrinol. Metab. 39: 1090-1098.

8. Kuku, S. F., J. B. Jaspan, D. S. Emmanouel, A. Zeidler, A. I. Katz, and A. H. Rubenstein. 1976. Heterogeneity of plasma glucagon. Circulating components in normal subjects and patients with chronic renal failure. J. Clin. Invest. 58: 742-750.

9. Weir, G. C., S. D. Knowlton, and D. B. Martin. 1975. High molecular weight glucagon-like immunoreactivity in plasma. J. Clin. Endocrinol. Metab. 40: 296-302.

10. Rigopoulou, D., I. Valverde, J. Marco, G. Faloona, and R.
H. Unger. 1970. Large glucagon immunoreactivity in extracts of pancreas. J. Biol. Chem. 245: 496-501.

11. Palmer, J. P., P. L. Werner, J. W. Benson, and J. W. Ensinck. 1976. Dominant inheritance of large molecular weight immunoreactive glucagon (IRG). Diabetes. 25(Suppl. 1): 326. (Abstr.)

12. Buchanan, K. D., and A. M. McCarroll. 1972. Abnormalities of glucagon metabolism in untreated diabetes mellitus. Lancet. II: 1394-1395.

13. Leichter, S. B., A. S. Pagliara, M. H. Greider, S. Pohl, J. Rosai, and D. M. Kipnis. 1975. Uncontrolled diabetes mellitus and hyperglucagonemia associated with an islet cell carcinoma. Am. J. Med. 58: 285-293.

14. Noe, B. G., and G. E. Bauer: 1975. Evidence for sequential metabolic cleavage of proglucagon to glucagon in glucagon biosynthesis. Endocrinology. 97: 868-877.

15. Noe, B. D., G. E. Bauer, M. W. Steffes, D. E. R. Sutherland, and J. S. Najarian. 1975. Glucagon biosynthesis in human pancreatic islets: Preliminary evidence for a biosynthetic intermediate. Horm. Metab. Res. 7: 314-322.

16. Hellerström, C., S. L. Howell, J. C. Edwards, A. Andersson, and G. C. Osternon. 1974. Biosynthesis of glucagon in isolated pancreatic islets of guinea pigs. Biochem. J. 140: 13-23.

17. O'Connor, K. J., and N. R. Lazarus. 1976. Studies on the biosynthesis of pancreatic glucagon in the pigeon (Columbia livia). Biochem. J. 156: 279-288.

18. Valverde, I., H. M. Lemon, A. Kessinger, and R. H. Unger. 1976. Distribution of plasma glucagon immunoreactivity in a patient with suspected glucagonoma. J. Clin. Endocrinol. Metab. 42: 804-808.

19. Danforth, D. N., Jr., T. Triche, J. L. Doppman, R. M. Beazley, P. V. Perrino, and L. Recant. 1976. Elevated plasma proglucagon-like component with a glucagonsecreting tumor. Effect of streptozotocin. N. Engl.J. Med. 295: 242-245.

20. Yalow, R. S., and S. A. Berson. 1970. Size and charge distinctions between endogenous human plasma gastrin in peripheral blood and haptodecapeptide gastrins. Gastroenterology. 58: 609-615.

21. Yalow, R. S., and S. A. Berson. 1973. Characteristics of "big ACTH" in human plasma and pituitary extracts. J. Clin. Endocrinol. Metab. 36: 415-423.

22. Goodman, A. D., R. Tanenbaum, and D. Rabinowitz. 1972. Existence of two forms of immunoreactive growth hormone in human plasma. J. Clin. Endocrinol. Metab. 35: 868-878.

23. Gorden, P., C. M. Hendricks, and J. Roth. 1973. Evidence for "big" and "little" components of human plasma and pituitary growth hormone.J. Clin. Endocrinol. Metab. 36: 178-184.

24. Deftos, L. J., B. A. Roos, D. Bronzert, and J. G. Pathemore. 1975. Immunochemical heterogeneity of calcitonin in plasma. J. Clin. Endocrinol. Metab. 40: 409-412.

25. Singer, F. R., and J. F. Habener. 1974. Multiple immunoreactive forms of calcitonin in human plasma. Biochem. Biophys. Res. Commun. 61: 660-666.

26. Day, R. P. , J. A. Luetscher, and C. M. Gonzales. 1975. Occurrence of big renin in human plasma, amniotic fluid and kidney extracts. J. Clin. Endocrinol. Metab. 40: 1078-1084. 